\title{
Cultural Tension in the Poetry of Iain Crichton Smith: An Integrative Phenomenological and Ontological Study
}

\author{
Emad Said Ibrahim \\ Department of English, Faculty of Arts, Menoufyia University \\ Assistant Professor, Department of English, Faculty of Science and \\ Arts, Shaqra University, Saudi Arabia
}

\begin{abstract}
The present study sheds light on the theme of tension, exhibited in examining the form and techniques in the poetry of Iain Smith. This study is concerned with the tension developing between the artist as an individual who craves for freedom of expression and a community that is controlled by the puritan law of the Scottish Free Church. The dialectical relationship involved introduces art as a synthesis nourished by the poetics of natural realism. The research adopts, thus, anontological, interpretive orientationin which social and historicalapproaches will be consulted, thus proving the poet's classical inclination which is driven by a realistic vision. This vision shall be defined through adopting a phenomenological practice regarding the text as phenomenato be explicated.
\end{abstract}

Keywords: Classical, culture, history, ontology, phenomenology, psychological, social.

\section{Introduction:}

Iain Crichton Smith, a Scottish poet and novelist, was born in 1928 and was brought up in the Gaelic-speaking community of Lewis. His father died when he was only two years old, so his mother acquired the role of both parents. He went to AberdeenUniversity and took a degree in English there. Smith has always been a writer whose work is based on the Highlands of Scotland. Alan Bold refers to this fact saying that "Smith has created his best poetry entirely through a sustained exploration of the insular world he inhabited"(Bold, 1982:215).

Smith has suffered from and has competed with what he considers as the narrowness of the world he grew up in, a narrowness caused by the teachings and the influence of the Free Church which he finds as dogmatic, authoritarian, and anti-cultural. The experience of release and affirmation that a poet is seeking goes, hence, ajar with what Smith finds in Lewis. In other words, Smith is put in a state of struggle with his immediate cultural and religious backgrounds. Living in a community dominated by the Calvinistic Free Church, that depends largely on rural crafts such as fishing, crafting, and shepherding, Smith hardly finds an attentive ear to his poetry. 
Such struggling concerns create tensions in Smith's poetry, tensions he believes to reside at the core of all good poetry. In a BBC talk on his poetry, Smith said: "I have always believed in a poetry which contains fighting tensions and not a poetry of statement"(qtd. In Bold, 1982: 218). Being at the borderline between two cultures, Smith remains there with these oppositions and prefers not to reach a conclusion. Edwin Morgan finds Smith's "poetry as not to affirm but to hold a balance"(Morgan, 1974: 221). It is the balance of poetic truth that Smith seeks. It is the sort of truth that Douglas Dunn describes as "disinterestedness", Dunn defines poetic truth as "a well-schooled disinterestedness on any subject under the sun whatever it is sorrow or delight. It permits a poet's images and narratives to go where they want instead of towards a conclusion pre-plotted by the practical necessities of taking sides or other kinds of intervention"(Dunn, 1992: 52).

Analytical, restrained, unsentimentalized are all suitable epithets to refer to Smith's poetry as well. Moreover, he is a poet who writes with the moral gravitas contending with the flighty Muse. Thus, Smith is a poet who seeks a crafted rather than an inspired poetry. Gerald Dawe judges Smith as a poet of classical inclinations, he finds that "Smith's clarity as a poet has an Augustan sense of compassion, satire and intellectual scrupulousness which neither diminishes its accessibility nor undermines its own artfulness in the interest of relevance"(Dawe, 1992: 76). Therefore, Smith's poetry is the outcome of the tensions he experiences. The strictness of the Free Church is, thus, echoed in the form of his poetry: written with observance of recognized rules, Smith's poetry is a mirror that reflects his vision of the world he lives.

Smith, thus, cruises disinterestedly between opposites, and this is a clear indication of his objectivity. Smith prefers, instead of taking one side rather than another, to stand aloof with an analytic look on the subjects that concern him. Referring to this tendency, Smith in prose writes: "I do tend to be analytic, ...I think myself that I would prefer to be an analytical poet, rather than a poet of the heart considered simply"(Smith, 1983:42). It is quite clear that Smith is a poet who favours conscious reality, thus inclined to adopt realistic vision.

Consequently, the present paper shall adopt phenomenology as an analytical method touching upon what really exists in a work of art as a text examined by a consciousness of a perceiver. Phenomenology "is a modern philosophical tendency that emphasizes the perceiver. Objects 
can have meaning ... only if an active consciousness (a perceiver) absorbs or notes their existence" (Bressler, 2003:77). Thus, phenomenology is an empirical philosophy that studies what appears. In defining what phenomenology is,Michael Lewis and TanjaStaehler find it as "a'science of the phenomenon,' but not 'phenomenon in the usual sense of a brief, dazzling coruscation. More literally, a phenomenon is something that appears; strictly speaking, it is the appearance itself" (Lewis,Michael and Staehler,Tanja, 2011:1). The ontological facet of the study will concentrate on the extrinsic approaches to literature specially the social and the historical as inseparable parts of cultural issues with which the poet contends.

\section{Conflicting tensions resolved in the realm of art.}

Smith is a poet who values the freedom of individual expression; however he lives within the confines of a puritan community that puts bars between him and his freedom of expression. Therefore, this study concentrates on Smith's refusal to coexist with those confines. "Poem of Lewis" from The Long River (1955) is an oft-anthologized poem to reveal the contending tensions that Smith lives in the Highlands. It is a poem that proves that " ... poetry is a mirror held up to the psyche, it reflects the reactions of the psyche against the age ..., its events, and current circumstances"(El-Komy, 2004: 18). Smith, in "Poem of Lewis", writes:

Here they have no time for the fine graces of poetry, unless it freely grows in deep compulsion, like water in the well, woven into the texture of the soil in a strong pattern. They have no rhythms to tailor the material of thought and snap the thread quickly on the tooth. One would have thought that this black north was used to lightening, crossing the sky like fish swift in their element. One would have thought the barren rock would give a value to the bursting flower. The two extremes, mourning and gaiety, meet like north and south in the one breast, milked by knuckled time, till dryness spreads across each aging bone. They have no place for the fine graces of poetry. The great forgiving spirit of the word 
fanning its rainbow wing, like a shot bird falls from the windy sky. The sea heaves in visionless anger over the cramped graves and the early daffodil, purer than a soul, is gathered into the terrible mouth of the gale. (Smith, 1995:2)

Malpas writes that"it is perhaps within the phenomenological framework that the most extensive explorations of concepts of space and place ... have been undertaken" (J. E. Malpas, 2007: 20).The poem starts with referring to a place or a community as a subject independent of the poet, and as the poem develops a separation or rather, a disparity between the subject and the poet is discovered. A dialectic is thus established between the poet and the nature of the community that is distanced from the "the fine graces / of poetry". Smith stresses the disparity between him and his community in comparing the kind of poetry he writes to the poetry that appeals for that community. Moreover,order and organization are kept in the presentation of the experience, the order that echoes the Free Church law's grasp over the place. The poet starts by naming the place, then he moves to refer to the nature of the community there, finally he shows the predicament of art at such a puritan community. Objectivity in exposing the case is not missed, for the poet is not totally inimical to that community.The diction used matches well the thought introduced: "texture", and "snap" are two powerfully meaningful words stressing again that tension. Hence, "texture" refers not only to the "woven" fabrics of a piece of cloth - a famous trade in the shepherding grounds of the Highlands - but also indicates the quality of a written text. The word "snap", on the other hand, does not only refer to the main craft, fishing, in the Highland, but also refers to a writing style of vagour and liveliness as well as an audible flipping rhythm.

Guided by the previous phenomenological descriptive stage, Smith emerges as a poet of a classical tendency shown through observing recognized rules of poetic creation.

Realistic works find becoming interpretation in the realm of ontology, thus a social interpretation could be employed to approach "Poem of Lewis". The title itself refers to a place and the community residing there; the poem also uncovers a social dialectic of relationships between the poet and his community both of which represent a different 
outlook on life. Smith is the educated poet, bearing the legacy of English literature, who yearns for the freedom of individual expression . His native community cannot allow such a freedom, for Lewis is a narrow community dominated by the restraint of the religious institution. Thus, the poem depicts the general structure of the society in Lewis which is repressed by the patriarchal authority of the Calvinistic Free Church whose influence Smith himself cannot escape. In prose he writes:

...sometimes I feel that there are a Free Church or religious element in me which are in conflict with my art .... Now, my attitude to the Free Church and religion is very ambivalent ... in one sense I think of it as constricting, and, in another sense, I admire the people who belong to that church because they represent, in a very strong and almost unquestioning way, things which I find very difficult and very complex ... So, religion is very important to me as force that I react against. (Smith, 1983:42)

Not only does religion practise a restrictive force over Smith, the social hierarchy of the type of professions represents another force. Lewis is a simple community of rural crafts such as fishing, farming, weaving, and shepherding, such a community cannot afford time for the leisure of enjoying poetry. However, they have their own kind of poetry that springs from their own wrestling with life and that matches their taste, originally formed by the church. Smith records,

... they have no time for the fine graces

of poetry, unless it freely grows

in deep compulsion, like water in the well, woven into the texture of the soil

in strong pattern.(Smith, 1995:2)

Smith's native community is still living in a primary phase of social development, whose craftsmen form the base and the persons of distinction in that society. Moreover, Lewis is a community of classless nature where managing a craft well is the sole judge on a person. Consequently, Lewis can be considered as a utopia where no place is offered for a poet of foreign taste. A writer that does not represent the taste of his society fails to accomplish the task for which he exists, that is why Smith ends the poem with shedding light on the theme of death. It is the death of the individual who feels alienated from his 
community. However, Smith has achieved a poem that could be considered as a true reflection of the social relationships in his native community. A community that is characterized by a dialectic of the individual's freedom versus the grasp of the community, for "throughout his early poems there are signs of Crichton Smith breaking with his community and its traditional labouring crafts, and of his establishing an independent existence as a writer and teacher"(Regan,1983: 65). The death of the "daffodil" at the encounter of a "gale" represents what Smith feels in his society, mainly a social death.

Smith traces the roots of his refusal to coexist with the existent cultural tensions he finds in Lewis to its historical sources. Smith echoes that tension on the relationship between the old generation, representing an authentic Gaelic culture, and the present generation, standing for the mainstream culture of the anglicized British isles. Two poems are selected for demonstrating this issue: "It is the Old" from The Law and the Grace (1965) and "Studies in Power" from Thistles and Roses (1961). In the former, Smith handles family relationships to reveal a deep rooted cultural dialectic depending on a paradoxical internal colonization:

It is the old

who get up in the night to build the fire for the young.

Their gods, they imagine, are disposed in a leisurely lazy heaven and prolong a Norman sleep against the cold and bitter frost.

And so they set a delicate structure of sticks, enfolded in this fear of their power, idolatry of their poise. Not knowing in Saxon dawns how the abyss their precarious tilt of sticks steadily lights is what their boys

dread in their beds, while dreaming of lords they can serve of brilliance courage and wit.

Roads are built on each nerve -

Roman and servile and powerful. Their needs 
point to the fire in the night. (Smith, 1995:53)

Within a poem of stanzaic structure, Smith introduces a reversed situation of familial relationships in which "the old" are presented as servants to "the young". Though family affairs are taken as subject, Smith exposes no passionate treatment of the issue even if he counts himself as belonging to the young. Thus, the dialectic here groups two extremes: the old Gaelic culture contrasted with the anglicized young, "their gods" assuming the prospect of the aristocratic Normans enslaving the natives. Smith, here, stands aloof as he examines the relationship between the two generations. In "It is the Old", "... the poem uses the family relationships between younger and older generations as a metaphor for the relations between indigenous populations and invaders who establish themselves as a social elite, turning the natives into a minimal class"(Milton, 1997:194).

The technique of the poem proves the classical inclination of Crichton Smith, an inclination that is formulated in the light of a glaringly realistic vision. "It Is the Old", thus, finds sound interpretation in the domain of ontology through adopting a historical-biographical approach. The poem offers a situation created by a historical and environmental determinism, for the selected approach "sees a literary work chiefly, if not exclusively, as a reflection of its author's life and times or the life and times of the characters in the work"(Guerin et al,1999: 22). In this poem, Smith stresses the circular motion of history that allocates sovereignty to succeeding nations depending on the element of power. Contemporary history shows the young anglicized generation in the Highlands as deriving their power from a faithfulness and servitude to the English culture of the mainland. On the other hand, Smith refers to the old generation as content with their servitude to the young:

It is the old

Who get up in the night to build the fires for the young.

Their gods, they imagine, are disposed

in a leisurely lazy heaven.(Smith, 1995:53)

Smith believes that the central incident that shaped modern Scottish history is the defeat of the Scottish Highland troops in the 1745 battle of Culloden. After that battle the Scots became divided into two classes, the anglicized young lords, and the simple highlanders owning no lands or houses. This condition, political and social, paved the way for more 
deterioration of the authentic Gaelic culture. Historical records shed more light on the topic:

Following the formal Act of Union in 1707, displeasure particularly amongst Highland Scots, supported the rebellions of 1715 and 1745 which attempted to restore the Old and Young (Bonnie Prince Charlie) pretenders to the throne of Scotland. After the battle of Culloden the Highland Clearances began, thousands were evicted from their rented crofts and the mass migration of Scots to other parts of the world began. Despite the popular view that the landlords were English, the majority were Scots, but not those of the Gaelic-speaking Roman Catholic tradition who had fought for the (Bonnie Prince). (qtd. in Smith,1983:65)

Therefore, the old who stand for the Gaelic culture, and in consequence to that historical situation, become servants for the young landlords "their boys" treated as "gods". Then, English becomes the official language and the Highland Scots had to leave their houses built with "a delicate structure of sticks".

However, Smith recalls the English being slaves to the Normans and the Romans to warn the young anglicized against the circular movement of history. The Gaels are treated now the same way as the English were treated under the Norman rule. This fact is not absent from the minds of the young generation, so they resort to a stronger power, that of the Romans, however "servile". The acceptance of the young's servitude is ironically echoed by the young's acceptance of the Roman's. Such a historical dialectic between the past authentic Gaelic tradition, a condition of "Non-being", and the present control of the young anglicized Scots, a state of pessimistic "Being", is resolved in a circular movement of "Becoming" leading to slavery. This state of continual "becoming" is the threat that Smith warns the young against so long as they remain not true to their native traditions.

Another poem, "Studies in Power" elaborates on the historical situation in the Highlands, this time Smith himself is personally involved.

Today at meeting while I sat confused

by motions, counter-motions, and the vague 


\section{Emad Said Ibrahim}

appalling ardour of the dialogue

I was struck by the terror (being thus bemused)

that I (O certainly no albatross

of a dear unearthly climate) should be there,

somehow a stranger, at a total loss

(no, not uncommon, let me be quite clear)

till this fear struck me with a dizzy force

that this was real and the poem I make

mere cardboard coins to fill a childish purse.

And I was terrified lest my world be fake and these blunt men who make all words opaque should stand like giants by my dwarfish verse.

I thought of power and its sources while the table tremble under a bronze thought and men grew marble of a dreaming sort all round me even here. Mile upon mile the violent and the beautiful strode on one in her deadly silks, the other in black Roman leather with the brassy belt and both impervious to my senseless guilt.

Till suddenly there I saw a vase in bloom gathering light about it clearly clearly in adult daylight not by a moon obscurely,

andits harder language filled the small room with its bare constant self, its paradigm of straining forces harmonized sincerely.(Smith, 1995:32)

The poem is made up of two parts each one is a sonnet divided into an octave and a sestet of two tercets. In the first part, Smith records his "meeting" with some representatives of his native community of Lewis. As the "dialogue" develops "ardour" between them, a disparity in interests has led the poet to feel "a stranger, at a total loss". This feeling is enhanced by an implied inferiority from the part of the poet as he distrusts his abilities as a poet capable of representing a real word in his 
poems. Thus, the present poem develops the same theme as found in the previous one, "It Is the Old", however it is the poet, representing the young generation, who feels inferior to the men of Lewis, the old generation. Smith, hence, stands with a "dwarfish verse" contrasted with the "blunt men" of the Highlands speaking in "opaque" "words". Therefore, the tension sustained to exist between the poet and the men of Lewis, a tension that marks a dialectic between the "opaque" words of those men and the poet's "verse" seen as "dwarfish". The poet's "verse" is introduced in a situation identical to a battle of "motions" and "counter-motions". In Smith's poetry there is marked "a conflict concerned with the status of art. Smith finds that the artist is not readily accepted or taken seriously by his society"(Alexander,1983: 119).

Having crafted a poem of an organized structure that has a powerful diction and objectivity in the exposition of thought, Smith affirms again his classical inclination as he observes classical rules of poetry writing. Smith adopts a realistic vision in "Studies in Power", a poem that meets the requirements of an ontological interpretation. A historical approach is employed to treat a poem that looms about the conflicting affiliations of cultural belonging.

"Studies in Power" speaks of two cultures : the authentic Gaelic, and the anglicized one represented, in its violence towards Gaeldom, by the Romans. Smith introduces the tension existent in a poem of two parts each of which is a sonnet. In the first part, Smith refers to his dialogue with the men of Lewis in terms of a battle lexical field, for, there is "motion, counter-motion", followed by his being "at a total loss" then he is "struck ... with a dizzy force", Smith should be most probably referring to the Picts, a "warlike tribe", who are the original inhabitants of Scotland. In the second part Smith speaks of a historical fact, namely the Roman colonization of Britain with "violent" "bronze" blades and "brassy belt(s)" surrounding "Roman leather". Therefore, in each sonnet Smith introduces a historical incident critical to his native culture, once by hinting as in the first sonnet, then by direct reference as in the second. Thus, upon writing the present poem Smith could have been influenced by the following historical record:

The Midlandvalley of Scotland represented the most northern extent of the Roman conquest of Britain after 79 A.D. Remnants of the Antonine Wall, which the Romans built between the River Forth and the River Clyde to defend this frontier, can still be 
seen. The lands to the north (known to the Romans as Caledonia) were occupied by a warlike tribe called Picts. Little is known about the Picts, but their origin and language is mostly Celtic. The more famous Hadrian's Wall, which is over 100 miles long and lies close to the current border between England and Scotland, was built by the retreating Romans (having been hurried by Pictish attacks) around 119 A.D. ((qtd. in Smith,1983:68))

Therefore, Smith takes a fact from history to denote the nature of the Gaelic culture originally formed by the brave Picts who were able to withstand the Roman sweeping invasion of their lands, the Highlands. On the other hand, the boastful English colonizer and the anglicized young generation of Scots, assuming superiority over the Gaels, were once inferior to the Roman colonizer. Smith, anglicized by education, acknowledges this fact, that is why he considers the Gael's talk as "more real" as issuing from a real people true to their culture and who speak its tongue. He finds himself alienated within his native borders for not being able to end the "dialogue" with the Gael since he has acquired another culture, and it is the sword of economy that has forced him to adopt the culture and language of the other. His poetry, thus, communicates a world that is not real to the Gaelic community whose talk he says:

... was real and the poems I make

mere cardboard coins to fill a childish purse.

And I was terrified lest my world be fake and these blunt men who make all words opaque should stand like giants by my dwarfish verse.(Smith, 1995:32)

However, Smith is conscious of the cultural defeat in Scottish contemporary history, for "...in Scotland as a whole there is a strong historical consciousness and it habitually dwells on defeat"(Bold, 1982: 219). Consequently, Smith, the young Gaelic poet, resorts to the Romans to derive both cultural and artistic powers. The Roman power has introduced "the beautiful" art and " the violent" military action, thus offering a dialectic of the contradictory faces of colonization. Smith, the young Gaelic artist, offers himself as a synthesis to resolve this cultural dialectic: the Anglo-Gaelic and the Anglo-Roman. Smith stands for the common or the mediatory aspect, the Roman order echoed in a classical poem that can communicate the Highlands' 
cultural and historical situation. This poem is envisioned as "a vase in bloom", an Augustan symbol of artistic perfection.

After showing the cultural characteristics of his native community of Lewis and examining its historical backgrounds, Smith reaches a conclusion based on the realistic principle of environmental determinism. Smith finds himself as formed and overpowered by that community having all its cultural characteristics embedded in his personality and art. "That Island Formed You" from the (1972) volume Love Songs and Elegies registers Smith's rejection of his community's narrowness and its inability to change:

That island formed you, its black hated men and stony bibles. How your father's beard streamed like a cataract. And the heart's devoured by the black rays of a descending sun. Always they're making fences, making barred gates to keep the wind out, their slow pace deliberate and punctual. Who has heard of the terrible cyclones that infect the deep space?

The daffodils are yellow on the wind but in these souls where is the love, my dear, to dally in fine leisure as the clear smoke rises from the houses, and the cock shrills redly from the waste abundant air?(Smith, 1995:134)

The poem introduces a statement of the inescapable influence of the environment by which an individual's life and consciousness are determined and "formed". Smith is aware of the powerful religious institution of "stony bibles" and acknowledges his being subjected to its influence, thus a dialectic between the individualistic artist and the puritan restraining system is expected to dominate the poem. Falling between two fighting tensions Smith, though as an integral part of the tension, maintains objectivity by avoiding the use of a speaking I: instead the second person pronoun "you" is used to mark a tone of argumentation having a meditative mode orderly presented. Order in exposing the thought is kept as the poet introduces the topic of concern, then he proceeds in offering explanations and consequences.

The classical form that depends on organization of thought echoes a realistic consideration of the environmental determinism. Smith's classicism appears in the objectivity practised in exposing thought in a 
powerful diction and functional figures of speech. Such a realistic perspective finds sound interpretation in the domain of ontology, specifically through applying a sociological approach. In the present poem, Smith sheds light on the social relationships in the Highlands that "formed" him. The poem reveals a community in which the puritan religious institution formulates the type of individual living there. Thus, a tension between a poet, who proves his existence by the practice of art, and that kind of community should result in. Lewis is an isolated and simple community falling in a primary stage of social and economic development, it is a closed society put under check by a puritan church. Therefore,
Always they're making fences, making barred gates to keep the wind out, there slow pace deliberate and punctual. Who has heard of the terrible cyclones that infect the deep space?(Smith, 1995:134)

The community is thus besieged within its local borders, so it gives no chance for a real change, whether social or intellectual. A dialectic, thus, is established between the poet introducing his art for the sake of an intellectual improvement and a puritan background. It becomes quite clear that "Crichton Smith has struggled as both poet and critic, with his immediate cultural and religious background. He has fought, as Auden did before him, with a recalcitrant introverted, separate background, in religious terms at least, presented itself as hostile to the imaginative life"(Dawe,1992: 73).

In the Lewis community, men of control and distinction are those saturated in religious constriction, their methods and laws have "devoured" an intellectual change that enriches the personality and improves the community. The control of the church appears in Smith's exclamatory sentence: "How your father's beard / streamed like a cataract". Smith alludes to the church's authority by referring to the patriarchal "father" whose "beard" with its priestly connotations is unendingly "streaming like a cataract". One of the meanings of the word "streaming" is the teaching of a group of children together as if in a parish, thus the whole community is being streamed by the religious institution that devours the "heart" and voids the "souls" of "love". Smith, hence, is fighting a social defect causing a voiding of the role of love and tolerance that fades in a puritan community. Thus Smith, seen as a social critic, introduces works that come coloured by the 
background he lives within, for critics of social orientation "approach the work of art on the basis that it is inevitably conditioned by the social circumstances and the current controlling powers in a certain age"(qtd. in El-Komy, 2004:189).

Smith lives within social conditions that beget a tension in the soul of a poet who tries to free his community from all forms of imprisonment both religious and cultural. He ,thus, becomes like a messenger of an intellectual renaissance, however the authority of the church is far more powerful. Smith is much like a "cock" who voices out a preaching of intellectual freedom that goes wastefully in "abundant air". Therefore, the state of ever existent fighting with tensions characteristic of Smith's poetry is the outcome of the social circumstances he witnesses in Lewis. Consequently, Smith has proved and has explained what is meant by the initial statement and title, " That Island Formed You".

\section{Conclusion}

The present study has been concerned with pinpointing the dialectical tensions that reside in the poetry of Iain Crichton Smith. It has exposed existing tension between Smith's individualistic fulfillment as an independent artist and a tradition of narrowness and suspicion of art in a society controlled by the puritan regulations of the Free Church. Another facet of the dialectic is the poet's revivalist concerns about the authentic culture of Gaelic Highlands and the relentless advance of the modern Anglicized culture threatening of British uniformity. The study has also proven that the realistic vision of the poet has shaped his classical technique. 


\section{Emad Said Ibrahim}

\section{References}

Alexander, J.H.(1983) "The English Poetry of Iain Crichton Smith."

inhis Literature of the North, Aberdeen university Press, 189-203.

--- (1992) "The Double Vision: Imagery in the English Poetry of Iain Crichton Smith."Iain Crichton Smith: Critical Essays. Ed. Colin Nicholson.Edinburgh: EdinburghUniversity Press, 131-143.

Bold, Alan (1982)"A Thematic Note on the Poetry of Iain Crichton Smith."The Malahat Review, No.62, July.215-22.

Bressler,Charles E, (2003)Literary Criticism: An Introduction to Theory and Practice,NewYork: Longman

Dawe, Gerald(1992) "Law and Grace: A Note on the Poetry of Iain

Crichton Smith."Iain Crichton Smith: Critical Essays. Ed.

Colin Nicholson.Edinburgh: Edinburgh University Press. 73-81.

Dunn, Douglas(1975) in Encounter, November. 76-7.

---(1976)"Natural Disorders." Encounter, Vol. xliv, No. 5, May, 73-6.

--- (1979)Ed. The Poetry of Scotland London: B.T. Batsford Ltd.

---(1982)"Elegies in Gaeldom."The Times Literary Supplement, No.

4141, August, 13,876.

--- (1992)"The Wireless Behind the Curtain."Iain Crichton Smith:

Critical Essays. Ed. Colin Nicholson.Edinburgh: Edinburgh

University Press, 51-72.

El-Komy, MohamadShebl(2003)Literary Theories: A Study in Modern

Egyptian Literature.Cairo: General Egyptian Book

Organization.

--- (2004)Schools of Modern Criticism: A Philosophical Approach.Cairo:

General Egyptian Book Organization.

--- (2005a)Literary Issues: A Philosophical Perspective.Cairo: General

Egyptian Book Organization.

---(2005b)Critical Issues: Practical Applications in the Relationships 
between Thought and Literature.Cairo: The General Egyptian Book Organization.

Guerin, Wilfred L. (et al)(1999)A Handbook of Critical Approaches to Literature. Oxford: O.U.P.

Lewis, Michael and Staehler,Tanja(2011)Phenomenology: An Introduction London:Continuum

Malpas, J. E. (2007) Place and Experience: A Philosophical Topography. Cambridge: Cambridge UP

Milton, Colin(1997) "Half of my Seeing: The English Poetry of Iain Crichton Smith." British Poetry From 1950s to the 1990s.Ed. Gary Day and Brium Docherty.London: Macmillan, 193-220.

Morgan, Edwin(1974) "The Raging and the Grace: Some Notes on the Poetry of Iain Crichton Smith", in his Essays, Carcanet New Press,222-31.

Regan, Stephan(1983) "Strong Patterns." Poetry Review, Vol.73, No.1, March, 64-7.

Smith, Iain Crichton(1983) "Towards the Human." inTowards the Human: Selected Essays. Loanhead: Loanhead Press, $13-70$

---(1995)Collected Poems. Manchester: Carcanet. 